\title{
Incorporation of 3-Aminobenzanthrone into 2 '-Deoxyoligonucleotides and Its Impact on Duplex Stability
}

\author{
Mark Lukin, Tanya Zaliznyak, Francis Johnson, and Carlos R. de los Santos \\ Department of Pharmacological Sciences, School of Medicine, Stony Brook University, Stony Brook, NY 11794-8651, USA \\ Correspondence should be addressed to Carlos R. de los Santos, cds@pharm.sunysb.edu
}

Received 8 July 2011; Accepted 3 September 2011

Academic Editor: Luis A. Marky

Copyright () 2011 Mark Lukin et al. This is an open access article distributed under the Creative Commons Attribution License, which permits unrestricted use, distribution, and reproduction in any medium, provided the original work is properly cited.

3-Nitrobenzanthrone (3NBA), an environmental pollutant and potent mutagen, causes DNA damage via the reaction of its metabolically activated form with the exocyclic amino groups of purines and the C-8 position of guanine. The present work describes a synthetic approach to the preparation of oligomeric $2^{\prime}$-deoxyribonucleotides containing a $2-\left(2^{\prime}\right.$-deoxyguanosin- $N^{2}-$ yl)-3-aminobenzanthrone moiety, one of the major DNA adducts found in tissues of living organisms exposed to 3NBA. The NMR spectra indicate that the damaged oligodeoxyribonucleotide is capable of forming a regular double helical structure with the polyaromatic moiety assuming a single conformation at room temperature; the spectra suggest that the $3 \mathrm{ABA}$ moiety resides in the duplex minor groove pointing toward the $5^{\prime}$-end of the modified strand. Thermodynamic studies show that the dG( $\left.N^{2}\right)-3 \mathrm{ABA}$ lesion has a stabilizing effect on the damaged duplex, a fact that correlates well with the long persistence of this damage in living organisms.

\section{Introduction}

Nitroarenes are widespread environmental pollutants found in cigarette smoke, coal fly ash, exhausts from diesel and gasoline engines, and air particulate matter [1]. 3-Nitrobenzanthrone (3NBA, 3-nitro-7H-benz[de] anthracen-7one), a member of this class of compounds, is one of the most potent bacterial mutagens known to date [2] and exhibits strong mutagenic activity in mammalian cells [3]. Human fibroblasts exposed to $\mathrm{N}$-acetoxy-3-aminobenzanthrone, an active metabolite of $3 \mathrm{NBA}$, show predominance of base substitution mutations mainly $\mathrm{G} \rightarrow \mathrm{T}$ transversions followed by $\mathrm{G} \rightarrow \mathrm{A}$ and $\mathrm{A} \rightarrow \mathrm{G}$ substitutions [4]. Transgenic mice treated with 3NBA exhibit increased mutation frequency in liver, colon, bladder, and bone marrow, with $\mathrm{G} \rightarrow \mathrm{T}$ transversions dominating this effect $[5,6]$. Analysis of 3NBA-induced mutations in mouse fibroblasts harboring a functional copy of the human p53 gene also reveals a preponderance of $\mathrm{G} \rightarrow \mathrm{T}$ transversions, followed by adenine base substitutions [7]. In addition to mutations, 3NBA causes DNA doublestrand breaks and induces the formation of micronuclei in human cell lines $[8,9]$. Female F344 rats treated with
3NBA by intratracheal instillation show acute and subacute changes in their lungs just few weeks after treatment and develop squamous cell lung tumors within 9 to 12 months, depending on the amount of 3NBA administered [10]. Some epidemiological evidence links environmental 3NBA exposure to lung cancer in humans $[11,12]$.

Like other environmental nitroarenes, 3NBA undergoes metabolic transformation to reactive electrophilic intermediates before binding to DNA and exerting its genotoxic effects. In rats, mice and humans, cytosolic $\mathrm{NAD}(\mathrm{P}) \mathrm{H}$ :quinone oxidoreductase (NQO1) is the main enzyme that reduces $3 \mathrm{NBA}$ to $\mathrm{N}$-hydroxy-3-aminobenzanthrone $(\mathrm{N}$ OH-3-ABA), which after further activation by phase II enzymes ( $\mathrm{N}-\mathrm{O} \mathrm{O}$-acetyl transferases, sulfotransferases) can react with DNA forming purine adducts (Figure 1) [13, 14]. NADPH:cytochrome P450 reductase can also activate 3NBA to reactive species in human cells [15], but its involvement seems to occur to a minor extent than that of NQO1. A fully reduced 3NBA metabolite, namely, 3-aminobenzanthrone (3ABA), has been recovered from urine of humans occupationally exposed to diesel exhaust [16]. 3ABA can undergo CYP1A1-mediated (or CYP1A2-) oxidation to the 


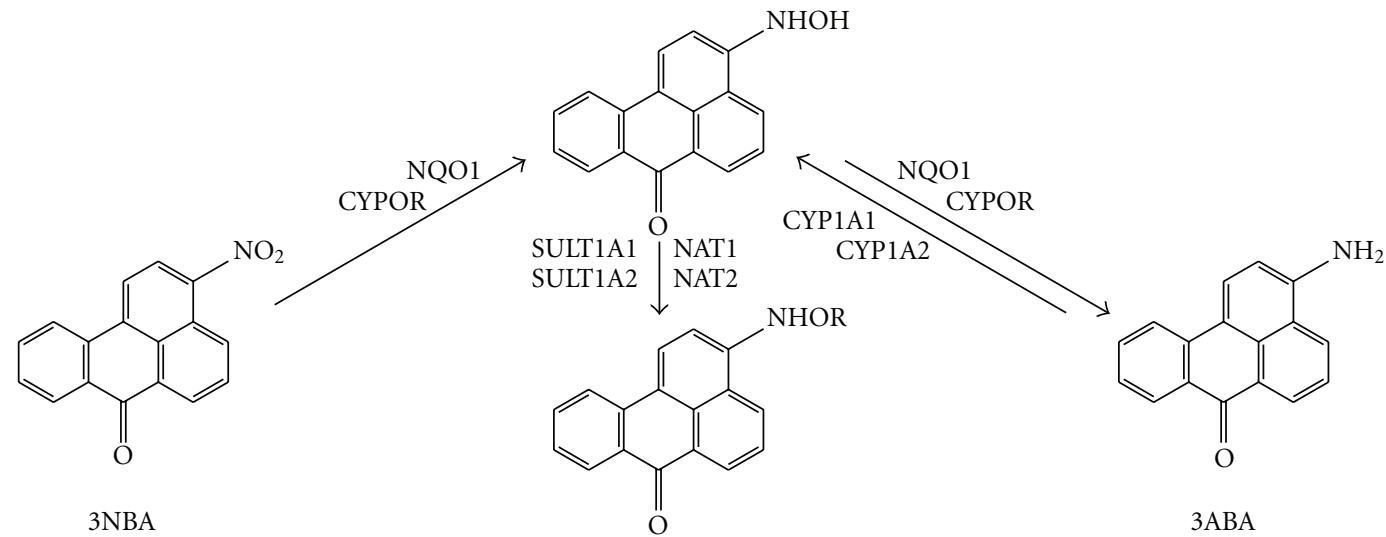

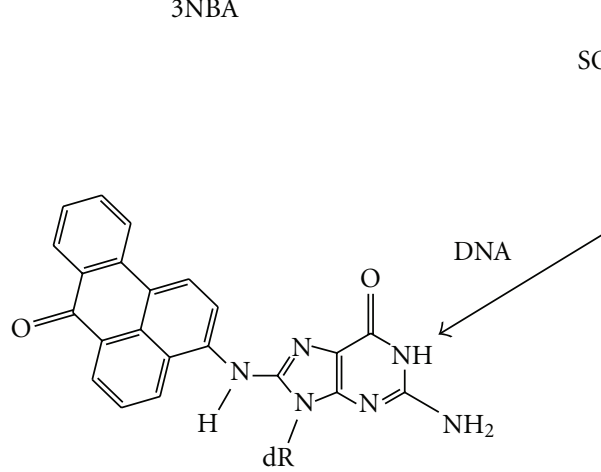

$\mathrm{dG}(\mathrm{C} 8)-\mathrm{ABA}$<smiles>CCn1cnc2c(=O)[nH]c(Nc3cc4c5c(cccc5c3N)C(=O)c3ccccc3-4)nc21</smiles><smiles>CCCn1cnc2c1N=CNC2Nc1cc2c3c(cccc3c1N)C(=O)c1ccccc1-2</smiles>

$\mathrm{dG}\left(N^{2}\right)-3 \mathrm{ABA}$

FIgURE 1: Metabolic activation of 3-nitrobenzanthrone and DNA adduct formation. NQO1, NAD(P)H:quinone oxidoreductase; CYPOR, NADPH:cytochrome P450 (P450) reductase; CYP1A1/2, cytochrome P450 1A1/2; NAT1A1/2, N,O acetyltranferases; SULT1A1/2, sulfotransferase 1A1/2; dG(C8)-ABA, $N$-(2'-deoxyguanosin-8-yl)-3-aminobenzanthrone; dG( $\left.N^{2}\right)-3 \mathrm{ABA}, 2$ - $\left(2^{\prime}\right.$-deoxyguanosin- $N^{2}$-yl)-3aminobenzanthrone; $\mathrm{dA}\left(N^{6}\right)-3 \mathrm{ABA}, 2-\left(2^{\prime}\right.$-deoxyadenosin- $N^{6}$-yl $)$-3-aminobenzanthrone. Numbering of the benzanthrone moiety is shown in the $\mathrm{dG}\left(N^{2}\right)$-3ABA adduct.

same $N$-hydroxyl intermediate generated by the reductive metabolism, indicating a further mechanism for the activation and the genotoxicity of $3 \mathrm{NBA}[17,18]$. In addition, because 3NBA induces increased levels of NQO1 and CYP1A1 proteins in rat lung and kidney tissues, its genotoxicity may be enhanced by autoinduction of its metabolic pathway [14].

The reactive metabolite of $3 \mathrm{NBA}, \mathrm{N}-\mathrm{OH}-3-\mathrm{ABA}$, can react with DNA in vitro and in vivo forming purine adducts. Up to five adducts are detected in rodent samples utilizing the TLC- ${ }^{32} \mathrm{P}$-postlabeling techniques with enrichment by butanol extraction $[5,19-21]$. HPLC comparison of these spots with synthetically prepared adduct standards [22] showed that 2-(2'-deoxyguanosin- $N^{2}$-yl $)-3$-aminobenzanthrone (dG( $\left.\left.N^{2}\right)-3 A B A\right), N$-(2'-deoxyguanosin-8-yl)-3aminobenzanthrone (dG(C8)-ABA), and 2-(2'-deoxyadenosin- $N^{6}$-yl)-3-aminobenzanthrone $\left(\mathrm{dA}\left(N^{6}\right)-3 \mathrm{ABA}\right)$ are the mayor adducts formed in rats organs after 3NBA administration [21]. Although the synthesis of the above- mentioned 3ABA adducts and their corresponding $\mathrm{N}$ acetyl forms has been reported [23], their incorporation in oligodeoxyribonucleotides has not been reportted. To understand the molecular mechanisms of 3NBA mutagenesis as well as the repair of 3NBA-damaged DNA, a procedure for the site-specific incorporation $3 \mathrm{ABA}$ lesions in oligomeric $2^{\prime}$-deoxyribonucleotides is essential. In the present article, we present a synthetic scheme that allows the preparation of oligomeric DNA containing the $\mathrm{dG}\left(N^{2}\right)$-3ABA adduct (Figure 1), one of the major DNA lesions generated by NBA in vivo [21]. The synthetic approach is robust permitting the incorporation of the adduct in any sequence context. We also present results showing that the presence of $\mathrm{dG}\left(N^{2}\right)$ $3 \mathrm{ABA}$ increases the stability of the damaged duplex, a finding previously observed with other $\mathrm{dG}\left(N^{2}\right)$ lesions, including the $N^{2}$-deoxyguanosine derivative of AAF, 2-(2'-deoxyguanosin$\mathrm{N}^{2}$-yl)-2-acetylaminofluorene [24]. Interestingly, both of these kinds of damage are characterized by an unusually long persistence in rat tissues $[21,25]$, suggesting that lack of 
thermodynamic destabilization by bulky lesions is a factor that hinders the recognition of the lesions by the nucleotide excision repair (NER) pathway.

\section{Materials and Methods}

2.1. Chemicals. All general chemicals were purchased from Sigma-Aldrich (St. Louis, Mo), and solid-phase DNA synthesis reagents from Glen Research Co. (Sterling, Va). S-benzyl thiotetrazole was crystallized from toluene and dried in vacuo over $\mathrm{P}_{2} \mathrm{O}_{5}$ before use.

2.2. Mass Spectrometry (MS). Electrospray ionization-mass spectrometry (ESI-MS) and tandem MS (MS/MS) experiments were carried out on TSQ Quantum Access (Thermo Scientific) and LTQ Orbitrap XL (Thermo-Fisher Scientific) spectrometers. A $50: 50: 1 \mathrm{v} / \mathrm{v}$ mixture of acetonitrile: water: triethylamine was used as the solvent for electrospray MS determinations. High-resolution mass spectra (HRMS) were acquired on the LTQ Orbitrap XL (ThermoFisher Scientific) equipped with an electrospray ionization (ESI) source. The spray voltage was set to $3.0 \mathrm{kV}$ and the temperature of the heated capillary was maintained at $300^{\circ} \mathrm{C}$. Measurements were done in a positive ion mode with an injection time of $200 \mathrm{~ms}$ and an infusion rate of $3 \mathrm{uL} / \mathrm{min}$ in $90 \%$ acetonitrile/water.

2.3. Stability Studies. Duplex denaturation profiles were recorded on a Cary 100 Bio UV-VIS spectrophotometer (Varian, Inc., Palo Alto, Calif). DNA duplexes were dissolved in $25 \mathrm{mM}$ sodium phosphate buffer, $\mathrm{pH} 6.8$, containing $150 \mathrm{mM} \mathrm{NaCl}$ and $500 \mu \mathrm{M}$ EDTA. Sample absorbance was recorded every $20 \mathrm{~s}$ within the $10-80^{\circ} \mathrm{C}$ range. Determinations proceeded while heating and cooling the sample, using a temperature change rate of $0.2^{\circ} \mathrm{C} / \mathrm{min}$. Duplex melting temperature $\left(T_{m}\right)$ was obtained by the first derivative method. Thermodynamic parameters were obtained from the analysis of $1 / T_{m}$ versus $\ln \left(C_{t}\right)$ plots (van't Hoff plots), whose slope and intercept yield $\Delta \mathrm{H}$ and $\Delta \mathrm{S}$, respectively [26].

2-(3',5'-Bis-O-Tert-Butyldimethylsilyl-O6-2-(4-Nitrophenylethyl)-2'-Deoxyguanosin- $N^{2}-y l$ )-3-Nitrobenzanthrone (1). It was synthesized according to a previously published procedure [23]. The final material was purified by crystallization from methanol, instead of the reported column chromatography method. The ${ }^{1} \mathrm{H}-\mathrm{NMR}$ spectrum of 1 was essentially identical to that previously published [23].

2-( $\mathrm{O}^{6}-2-(4-N i t r o p h e n y l e t h y l)-2^{\prime}-$ Deoxyguanosin- $\left.N^{2}-y l\right)-$ 3-Nitrobenzanthrone (3). Silylated nucleoside 1 (255 mg, $0.25 \mathrm{mmol}$ ) was dissolved in $3 \mathrm{~mL}$ of a dimethylformamide: triethylamine trihydrofluoride: triethylamine mixture $(6: 4: 3)$ and heated at $50^{\circ} \mathrm{C}$ for 1 hour. The mixture was poured into $50 \mathrm{~mL}$ of ethyl acetate, centrifuged, the residue rinsed with ethyl acetate, and dried in vacuo over $\mathrm{P}_{2} \mathrm{O}_{5}$, yielding $131 \mathrm{mg}(0.19 \mathrm{mmol}, 78 \%)$ of 3 as a fine red powder. For NMR spectroscopy, the sample was resuspended in ethyl acetate, centrifuged, and dried. ${ }^{1} \mathrm{H}-\mathrm{NMR}$ (DMSO- $d_{6}$,
TMS, $\delta$ (p.p.m.)): 9.87 (br. s., $1 \mathrm{H}), 9.20$ (s. $1 \mathrm{H}), 8.55$ (d, $1 \mathrm{H}), 8.49(\mathrm{~d}, 1 \mathrm{H}), 8.32(\mathrm{~s}, 1 \mathrm{H}), 8.28(\mathrm{~m}, 2 \mathrm{H}), 7.99(\mathrm{t}, 1 \mathrm{H})$, $7.92(\mathrm{~d}, 2 \mathrm{H}, J=8.0 \mathrm{~Hz}), 7.83(\mathrm{t}, 1 \mathrm{H}), 7.66(\mathrm{t}, 1 \mathrm{H}), 7.37(\mathrm{~d}$, $2 \mathrm{H}, J=8.0 \mathrm{~Hz}), 6.29(\mathrm{t}, 1 \mathrm{H}, J=6.0 \mathrm{~Hz}), 5.21($ br s, $1 \mathrm{H})$, 4.83 (br s, $1 \mathrm{H}$ ), 4.66 (br s, $2 \mathrm{H}$ ), 4.31 (br s, $1 \mathrm{H}$ ), 3.81 (br s, $1 \mathrm{H}) 3.50-3.46(\mathrm{~m}, 3 \mathrm{H}), 2.63-2.52(\mathrm{~m}, 2 \mathrm{H})$ (Supplementary Material available at doi: 10.4061/2011/521035). ${ }^{13} \mathrm{C}-\mathrm{NMR}$ (DMSO- $d_{6}$, TMS, $\delta$ (p.p.m.)): 128.23, 159.00, 154.67, $153.08,146.17,146.08,139.78,137.86,134.34,133.98$, $132.60,130.27,129.97,129.56,128.20,127.58,127.32$, $124.99,124.55,123.82,123.17,123.05,116.37,87.84,83.10$, 70.66, 66.07, 61.56, 45.60, 34.13 (Supplementary Material). HRMS: observed $[\mathrm{M}+\mathrm{H}]^{+}$690.1923; calculated 690.1943.

\section{2-(5'-O-Dimethoxytriphenylmethyl-O ${ }^{6}-2-(4-N i t r o p h e n y l-$} ethyl)-2'-Deoxyguanosin- $\left.N^{2}-y l\right)-3-N i t r o b e n z a n t h r o n e$ Nucleoside 3 (120 mg, $0.17 \mathrm{mmol}$ ) was coevaporated with pyridine, redissolved in $2 \mathrm{~mL}$ of dry pyridine, mixed with $120 \mathrm{mg}$ of dimethoxytrityl chloride $(0.35 \mathrm{mmol})$, and left for 12 hour at room temperature. After disappearance of the starting material (estimated by TLC analysis), the reaction mixture was diluted with $20 \mathrm{~mL}$ of ethyl acetate, extracted with $10 \%$ sodium citrate $(3 \times 100 \mathrm{~mL})$, dried with sodium sulfate, and evaporated in vacuo. Flash chromatographic purification of the residue (5\% triethylamine in methylene chloride) yielded $123 \mathrm{mg}(0.125 \mathrm{mmol}, 73 \%)$ of 4 as a deep red transparent glassy solid. ${ }^{1} \mathrm{H}-\mathrm{NMR}\left(\mathrm{CDCl}_{3}, \mathrm{TMS}, \delta\right.$ (p.p.m.)): 9.93 (s, 1H), 9.21 (s, 1H), 8.68 (d, $1 \mathrm{H}, J=6.5 \mathrm{~Hz}$ ), $8.50(\mathrm{~d}, 1 \mathrm{H}, J=6.9 \mathrm{~Hz}), 8.49(\mathrm{~d}, 1 \mathrm{H}, J=8.7 \mathrm{~Hz}), 8.39(\mathrm{~d}$, $1 \mathrm{H}, J=8.7 \mathrm{~Hz}), 8.12(\mathrm{~d}, 2 \mathrm{H}, J=8.3 \mathrm{~Hz}), 7.98(\mathrm{~s}, 1 \mathrm{H})$, $7.90(\mathrm{t}, 1 \mathrm{H}, J=7.8 \mathrm{~Hz}), 7.8(\mathrm{t}, 1 \mathrm{H}, J=7.5 \mathrm{~Hz}), 7.63(\mathrm{t}$, $1 \mathrm{H}, J=7.0 \mathrm{~Hz}), 7.47(\mathrm{~d}, 2 \mathrm{H}, J=8.0 \mathrm{~Hz}), 7.38(\mathrm{~d}, 2 \mathrm{H}$, $J=7.2 \mathrm{~Hz}), 7.28-7.26(\mathrm{~m}), 6.78(\mathrm{~d}, 4 \mathrm{H}, J=8.2 \mathrm{~Hz}), 6.58$ $(\mathrm{t}, 1 \mathrm{H}, J=6.1 \mathrm{~Hz}), 4.83(\mathrm{t}, 2 \mathrm{H}, J=7.2 \mathrm{~Hz}), 4.67(\mathrm{~m}$, $1 \mathrm{H}), 4.21(\mathrm{~m}, 1 \mathrm{H}), 3.76(\mathrm{~s}, 6 \mathrm{H}), 3.44(\mathrm{~m}, 1 \mathrm{H}), 3.35-3.30$ $(\mathrm{m}, 3 \mathrm{H}), 2.85$ (br s, 1H), 2.81-2.79 (m, 1H), 2.65-2.64 $(\mathrm{m}, 1 \mathrm{H})$ (Supplementary Material). ${ }^{13} \mathrm{C}-\mathrm{NMR}\left(\mathrm{CDCl}_{3}\right.$, TMS, $\delta$ (p.p.m.)): 183.2, 160.8, 158.8, 154.0, 153.5, 152.6, $150.4,147.0,145.8,144.6,139.0,135.8,135.7,134.3,134.2$, $133.2,131.2,130.7,130.3,130.2,130.1,129.3,129.1,128.3$, $128.2,128.0,127.9,127.6,127.2,125.9,123.9,123.2,117.6$, $116.2,115.0,114.5,113.5,113.4,87.0,86.9,83.9,72.9,68.1$, 67.2, 56.1, 56.0, 55.4, 52.9, 46.0, 32.2, 25.7 (Supplementary Material). HRMS: observed $[\mathrm{M}+\mathrm{H}]^{+}$992.3227, calculated 992.3250 .

2-(3'-O-(Cyanoethoxydiisopropylaminophosphino)-5' -ODimethoxytriphenylmethyl-O ${ }^{6}-2-(4-N i t r o p h e n y l e t h y l)-2^{\prime}-$ Deoxyguanosin- $N^{2}-y l$ )-3-Nitrobenzanthrone (5). Nucleoside 4 (112 mg, $0.11 \mathrm{mmol}$ ) was coevaporated with toluene, dissolved in $2 \mathrm{~mL}$ of dry THF under argon, mixed with $200 \mu \mathrm{L}$ of diisopropyl ethylamine, followed by the addition of $104 \mu \mathrm{L}(0.37 \mathrm{mmol})$ of 2-cyanoethoxy diisopropyl chlorophosphoramidite. The mixture remained at room temperature for 6 hours. After disappearance of the starting material (assayed by TLC analysis), the mixture was dissolved in $30 \mathrm{~mL}$ of ethyl acetate and washed with $10 \%$ potassium carbonate $(2 \times 50 \mathrm{~mL})$. The organic layer was dried with 


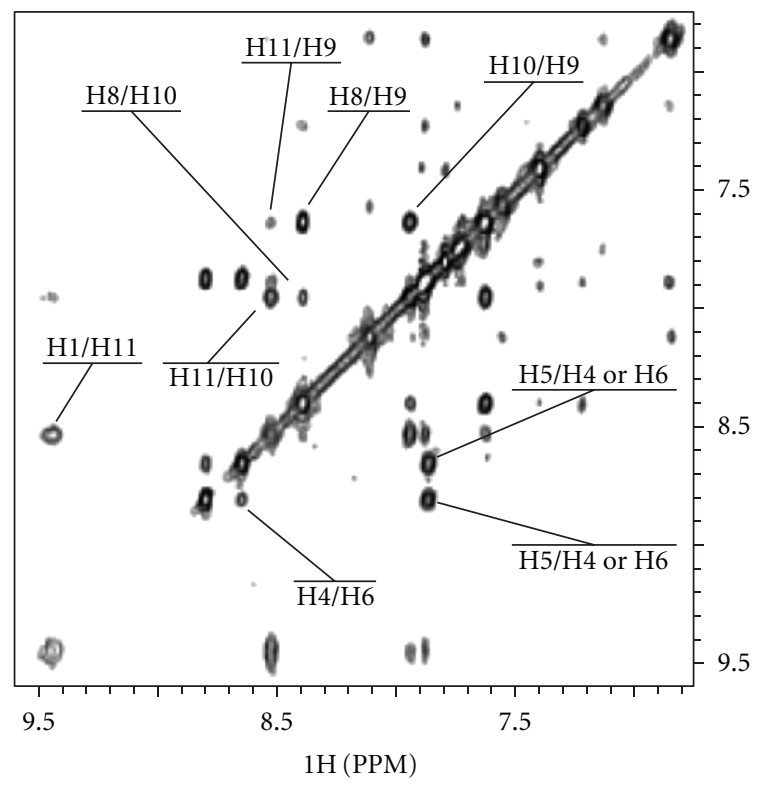

(a)

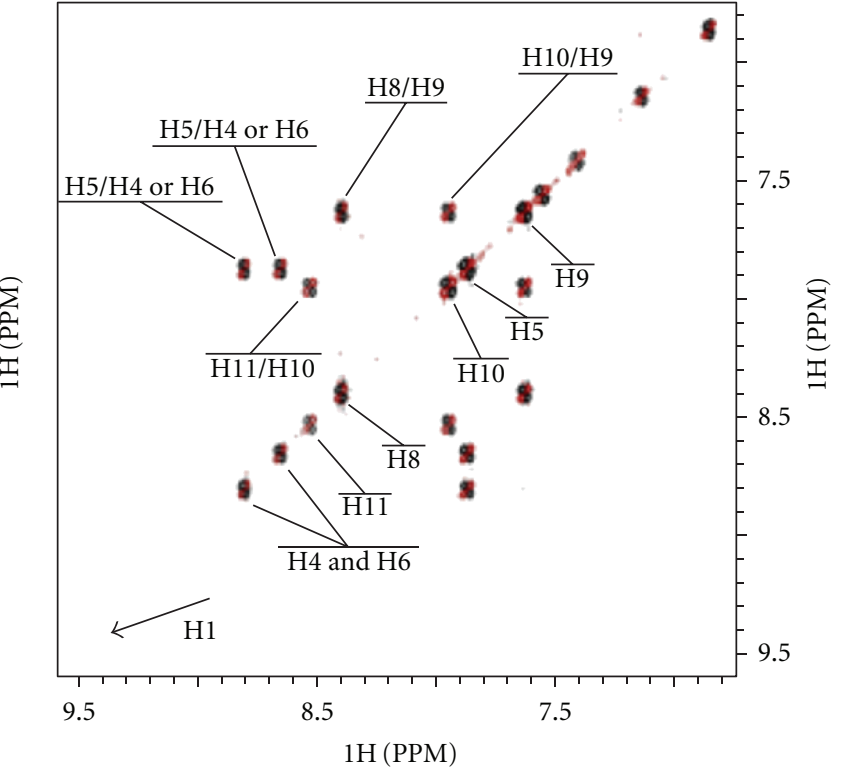

(b)

FIGURE 2: Expanded contour plot of a $300 \mathrm{~ms}$ mixing time NOESY spectrum $(600 \mathrm{MHz})$ of the 14 -mer dG $\left(N^{2}\right)-3 \mathrm{ABA}$ duplex dissolved in $100 \% \mathrm{D}_{2} \mathrm{O}$ phosphate buffer, $\mathrm{pH} 6.9$ (left), depicting NOE interactions among the aromatic protons of the duplex. NOE peaks are particularly strong among the aromatic 3ABA protons facilitating their assignment. Especially relevant is the 3ABA(H1-H11) cross-peak which allows identification of the different aromatic rings. Identical region of a DQF-COSY spectrum recorded under the same conditions (right) showing J-coupling interactions that confirms the NOE-based assignments. The arrow points to the position of the H1 diagonal peak, which is missing on the DQF-COSY spectrum due to the absence of coupling interactions. Labels show the specific assignments of the aromatic protons of $3 \mathrm{ABA}$, with the exception of $\mathrm{H} 4$ and $\mathrm{H} 6$ where it was not possible. The numbering scheme is shown in Figure 1.

sodium sulfate and evaporated in vacuo. The resulting viscous oil was purified by reverse-phase chromatography using an acetonitrile-water gradient $(60-100 \%$, over $15 \mathrm{~min})$ as the mobile phase, yielding 5 ( $98 \mathrm{mg}, 0.082 \mathrm{mmol}, 74 \%$ ) as a deep-red colored transparent glassy solid. The ${ }^{1} \mathrm{H}-\mathrm{NMR}$ spectrum had a double set of signals, of 55-45 intensity ratio, which corresponded to the diastereomers related to the phosphorus atom. ${ }^{1} \mathrm{H}-\mathrm{NMR}\left(\mathrm{CDCl}_{3}\right.$, TMS, $\delta$ (p.p.m.), chemical shifts for the major component are (given when possibe) $9.79(\mathrm{~s}, 1 \mathrm{H}), 9.82(\mathrm{~s}, 1 \mathrm{H}), 8.71(\mathrm{~d}, 1 \mathrm{H}), 8.52(\mathrm{~d}$, $1 \mathrm{H}), 8.50(\mathrm{~d}, 1 \mathrm{H}), 8.37(\mathrm{t}, 1 \mathrm{H}), 8.10(\mathrm{t}, 1 \mathrm{H}), 8.00(\mathrm{~s}, 1 \mathrm{H})$, $7.92(\mathrm{t}, 1 \mathrm{H}), 7.73(\mathrm{t}, 1 \mathrm{H}), 7.63(\mathrm{t}, 1 \mathrm{H}), 7.43-7.39(\mathrm{~m}, 4 \mathrm{H})$, 7.29-7.17 (m), $7.19(\mathrm{t}, 1 \mathrm{H}), 7.90(\mathrm{~d}, 2 \mathrm{H}), 7.60(\mathrm{~d}, 2 \mathrm{H}), 6,50$ $(\mathrm{m}, 1 \mathrm{H}), 4.82($ br t, $2 \mathrm{H}), 4.72(\mathrm{~m}, 1 \mathrm{H}), 4.28(\mathrm{~m}, 1 \mathrm{H}), 3.76(\mathrm{~s}$, $3 \mathrm{H}), 3.75(\mathrm{t}, 3 \mathrm{H}), 3.66-3.43(\mathrm{~m}, 4 \mathrm{H}), 3.44-3.35(\mathrm{~m}, 2 \mathrm{H})$, 3.30 (br t, $2 \mathrm{H}), 2.86$ (sept, $1 \mathrm{H}), 2.71(\mathrm{~m}, 1 \mathrm{H}), 2.45(\mathrm{~m}, 1 \mathrm{H})$, $1.53(\mathrm{~m}, 12 \mathrm{H})$ (Supplementary Material). HRMS: observed $[\mathrm{M}+\mathrm{H}]^{+}$1192.4365, calculated 1192.4328.

2.4. Oligodeoxyribonucleotide Synthesis. It was performed on an ABI DNA synthesizer using UltraMild CE phosphoramidites and $S$-benzylthio-tetrazole as the activator reagent. Standard procedures were used for the preparation of unmodified oligodeoxyribonucleotides. A four-fold molar excess of amidite was used and the coupling time was increased to 5 minutes for introduction of the xenonucleotide moiety. Oligodeoxyribonucleotide cleavage from the solid support and subsequent deprotection was accomplished by overnight incubation with concentrated aque- ous ammonia at room temperature. After evaporation in vacuo, the synthetic products were purified by reverse-phase chromatography. Purification was performed on a Gilson HPLC system with UV monitoring at 260 and $290 \mathrm{~nm}$, a $7.5 \times 250 \mathrm{~mm}$ Zorbax ODS column $(5 \mu \mathrm{M}$ particle size, $300 \AA$ pore size), using a linear acetonitrile gradient (5 to $50 \%$, $30 \mathrm{~min}$ ) in $50 \mathrm{mM}$ triethylammonium acetate, $\mathrm{pH} 6.5$, at flow rate of $5 \mathrm{~mL} / \mathrm{min}$. Purified oligodeoxyribonucleotides were lyophilized and the $5^{\prime}$-DMT group was removed by coevaporation with an $80 \%$ acetic acid solution. The residue was dissolved in $2 \mathrm{~mL} 1 \mathrm{M}$ tetrabutylammonium chloride, purified by HPLC using the protocol described above, and lyophilized to dryness. The resulting product was dissolved in water $(1 \mathrm{~mL})$ and $100 \mu \mathrm{L} 1 \mathrm{M}$ sodium sulfide was added. The immediate color transition from an orange-red to a deep purple attested that the reduction of nitro group had taken place. After standing for $1 \mathrm{hr}$ at room temperature, the reaction mixture was purified by HPLC yielding the desired oligodeoxyribonucleotide product, which was lyophilized, precipitated from ethanol in sodium form and subsequently desalted using a Sephadex G-10 column.

2.5. NMR Spectra. One- and two-dimensional ${ }^{1} \mathrm{H}$ NMR spectra were recorded using Varian (Inova) or Bruker (Avance) spectrometers operating at 9.4, 11.75, or $14.1 \mathrm{~T}$ field strengths. Proton chemical shifts were referenced relative to tetramethyl silane (for organic solvents) or sodium 3(trimethylsilyl) propionate-2,2,3,3- $d_{4}$ (for water solutions) at $0 \mathrm{ppm}$. Phase-sensitive NOESY (300 ms mixing times) and 


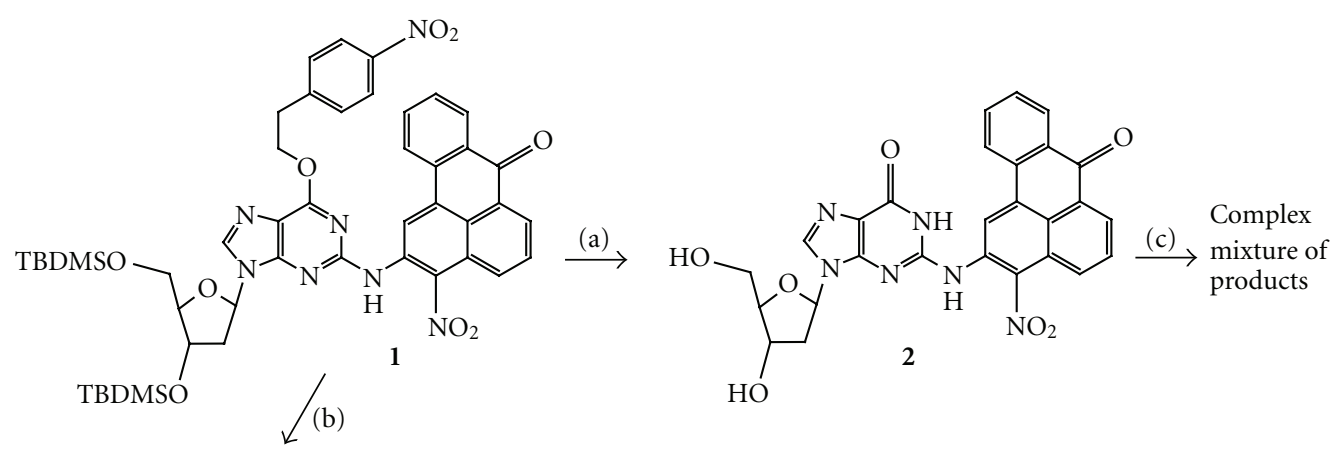<smiles></smiles>

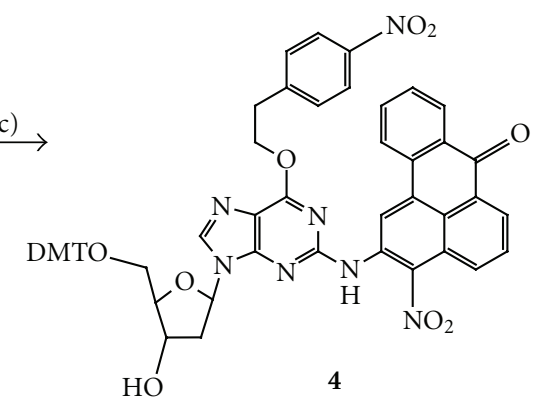

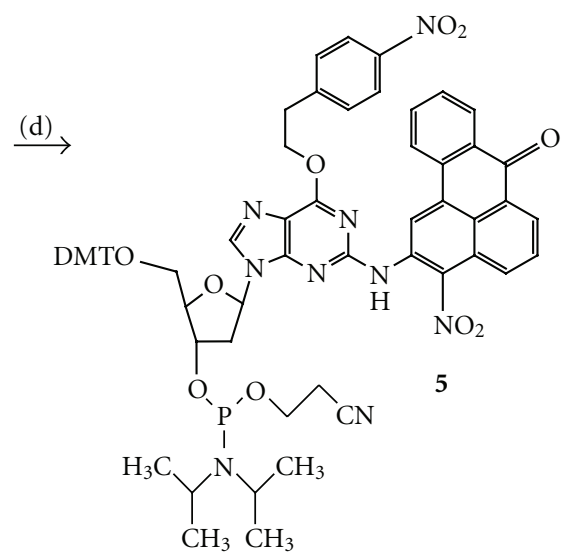

Scheme 1: Synthesis of protected dG(N2)-3ABA phosphoramidite. (a) $1 \mathrm{M}$ tetrabutylammonium fluoride, THF; (b) triethylamine trihydrofluoride : triethylamine: DMF (4:3:6); (c) dimethoxytrityl chloride, pyridine; (d) cyanoethoxy diisopropylamino chlorophosphine.

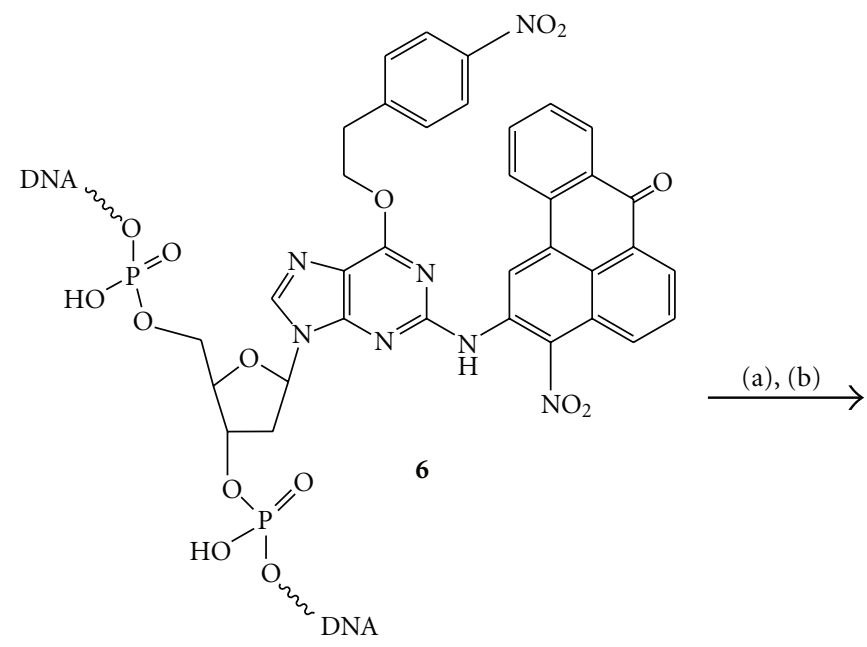<smiles>N#COP(=O)(O)OC1CC(n2cnc3c(=O)[nH]c(Nc4cc5c6c(cccc6c4N)C(=O)c4ccccc4-5)nc32)OC1COP(=O)(O)O[W]#N</smiles>

Scheme 2: Deprotection and nitro reduction of $\mathrm{dG}\left(\mathrm{N}^{2}\right)$-NBA in oligonucleotides. (a) $1 \mathrm{M}$ tetrabutylammonium fluoride, THF; (b) $1 \mathrm{M}$ $\mathrm{Na}_{2} \mathrm{~S}$.

DQF-COSY spectra of the damaged duplex were collected at $25^{\circ} \mathrm{C}$ with the sample dissolved in $50 \mathrm{mM}$ phosphate buffer solution ( $\mathrm{pH}$ 6.9) in $100 \% \mathrm{D}_{2} \mathrm{O}$. The residual water signal was suppressed by presaturation during the repetition delay of $1.5 \mathrm{~s}$. NMR data were processed and analyzed using NMRPipe [27] and Sparky [28], running in Linux workstations. Datasets consisted of 4096 and 256 complex data points in the $t_{2}$ and $t_{1}$ dimensions, respectively. Time 
G1 T2 A3 T4 X5 C6 C7 G8 G9 C10 A11 T12 A13 C14 C14A13 T12 A11C10 G9 G8 C7 C6 X5 T4 A3 T2 G1

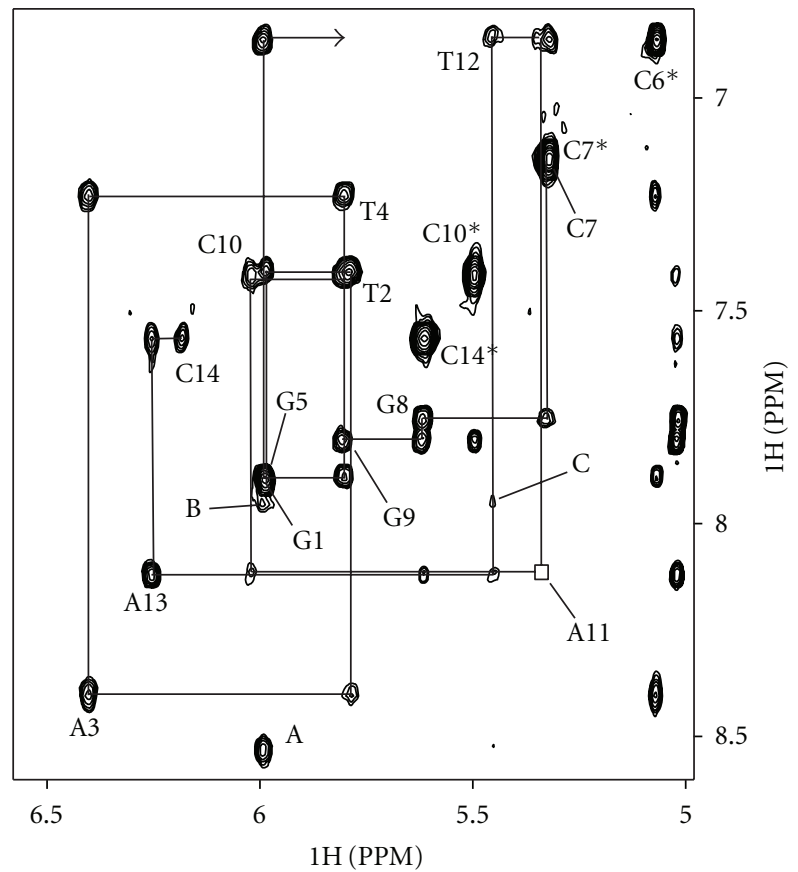

FIGURE 3: Expanded contour plot showing the finger print region of a $300 \mathrm{~ms}$ mixing time NOESY spectrum $(600 \mathrm{MHz})$ of the 14-mer $\mathrm{dG}\left(N^{2}\right)$-3ABA duplex dissolved in $100 \% \mathrm{D}_{2} \mathrm{O}$ phosphate buffer, $\mathrm{pH}$ 6.9. The labels identify cross-peaks between the purine $(\mathrm{H} 8)$, or pyrimidine $(\mathrm{H} 6)$, and the $\mathrm{H}^{\prime}$ sugar proton of the same residue. Asterisks indicate cytosine $(\mathrm{H} 5-\mathrm{H} 6)$ interactions. Other labels are assigned as follows: A, 3ABA(H2)-G5(H1'); B, $3 \mathrm{ABA}(\mathrm{H} 3)-\mathrm{G} 5\left(\mathrm{H}^{\prime}\right)$; $\mathrm{C}, 3 \mathrm{ABA}(\mathrm{H} 3)-\mathrm{T} 12\left(\mathrm{H}^{\prime}\right)$. The arrow points to the position of $\mathrm{C} 6\left(\mathrm{H}^{\prime}\right)$ that resonates outside of the plotted region, at $4.43 \mathrm{ppm}$.

domain data were multiplied by a shifted sine-bell window function and zero filled to 4096 points. Polynomial baseline correction was applied to the frequency domain data.

\section{Results and Discussion}

\subsection{Preparation of the $d G\left(N^{2}\right)-3 A B A$ Containing Oligode-} oxyribonucleotide. A general synthetic method for the introduction of modified $\mathrm{dG}$ moieties having aminoaryl or $\mathrm{N}$ acetylaminoaryl substitutions (xenonucleotides) is the use of the 2-(N-trifluoroacetylaminoaryl)-deoxyguanosine phosphoramidite during conventional phosphoramidite solid phase synthesis [29]. In this approach, the key nitroarene precursor is obtained via a palladium-mediated condensation of protected $2^{\prime}$-deoxyguanosine with the corresponding bromo nitroarene [30], followed by deprotection, nitroreduction and trifluoroacetylation. Despite its simplicity and versatility, this method showed some drawbacks in the $\mathrm{dG}\left(N^{2}\right)-3 \mathrm{ABA}$ case. First, the direct reduction of the nitro group and ensuing trifluoroacetylation lead to a complex mixture of products, a complication that, in principle, can be prevented by using additional deprotection and protection steps. Second, the use of trifluoroacetyl protection imposes some restrictions on the conditions of solid phase synthesis and oligodeoxyribonucleotide deprotection that reduced final yields. To overcome these problems, we decided to introduce $\mathrm{dG}\left(N^{2}\right)$-3NBA directly during oligodeoxyribonucleotide synthesis and generate the amino group of the adduct by a postsynthesis treatment. Using standard procedures $[23,30]$, we readily prepare the protected $\mathrm{dG}\left(N^{2}\right)$-3NBA nucleoside $(\mathbf{1})$. Treatment of $\mathbf{1}$ with TBAF removes the oxygen protecting groups (TBDMS and $\mathrm{p}-\mathrm{NO}_{2}$ phenetyl (NPE)), yielding the fully deprotected adduct (2) (Scheme 1). This compound, however, produces a complex mixture of products during the subsequent synthesis steps (data not shown), making it an unsuitable intermediate. A possible explanation is that the unprotected $\mathrm{dG}\left(N^{2}\right)$ 3NBA (2) has poor solubility in both water and organic solvents, impeding its purification by standard treatments including liquid-liquid extraction and column chromatography. In addition, this compound seems to exist in several protonation states, a fact easily seen by sharp color changes, from violet-purple to deep blue to deep green, upon transition to higher $\mathrm{pH}$. Therefore, we decided to keep the guanine- $\mathrm{O}^{6}$ protecting group on during the phosphoramidite preparation and solid phase synthesis. Treatment of (1) with a TEA-3HF: TEA:DMF mixture removes the TBDMS protection leaving the NPE group intact. Nucleoside (3) is then $5^{\prime}$-dimethoxytritylated to give 4 which, in turn, is converted to the corresponding phosphoramidite (5) using the standard protocol (Scheme 1). Coupling of the xenonucleotide phosphoramidite shows 90-95\% efficiency during solid phase oligonucleotide synthesis.

We tested two possible approaches for the postsynthetic deprotection of the oligodeoxyribonucleotide and reduction of the nitro group. The first one was the removal of the guanine- $\mathrm{O}^{6}$ protecting group by treatment of the synthesis product, still attached to the solid support, with $1 \mathrm{M} \mathrm{DBU} /$ DMF, followed by reduction of the nitro group with $1 \mathrm{M}$ sodium dithionite/sodium citrate at $\mathrm{pH}$ 7.0. Subsequent treatment with concentrated ammonia should remove the other protecting groups and cleave the oligodeoxyribonucleotide from the solid support. However, during the ammonia treatment we observed considerable color changes, suggesting a partial degradation of the $\mathrm{dG}\left(N^{2}\right)$-3ABA moiety and the final yield was unacceptably low for large-scale synthesis. Utilization of mild deprotection phosphoramidites diminished the problem but did not eliminate it. Therefore, we used an alternative strategy that proved to be successful. After solid phase synthesis, treatment with concentrated ammonia at room temperature cleaved the tritylated oligodeoxyribonucleotide from the solid support and removed the acyl and cyanoethyl protecting groups. After solvent evaporation and purification by reverse phase HPLC, ESI-MS confirmed that the major product was the NPE-protected $\mathrm{dG}\left(N^{2}\right)$-3NBA containing oligomer (6). Subsequent treatment with TBAF removed the NPE protecting group and addition of $1 \mathrm{M} \mathrm{Na} \mathrm{Na}_{2} \mathrm{~S}$ reduced the nitro group of $\mathrm{dG}\left(N^{2}\right)$ $3 \mathrm{NBA}$ to the corresponding amino of $\mathrm{dG}\left(N^{2}\right)-3 \mathrm{ABA}(7)$ with excellent yields (Scheme 2). After purification of the reaction products by an additional HPLC run, ESI-MS analysis 
TABLE 1: Thermodynamic parameters of ABA-modified and unmodified tetradecamer duplexes.

\begin{tabular}{lccccc}
\hline & $\Delta H_{25}^{\circ}, \mathrm{kcal} / \mathrm{mol}$ & $\Delta S_{25}^{\circ}, \mathrm{cal} / \mathrm{mol} \cdot \mathrm{K}$ & $\Delta G_{25}^{\circ}, \mathrm{kcal} / \mathrm{mol}$ & $\Delta G_{37}^{\circ}, \mathrm{kcal} / \mathrm{mol}$ & $\Delta \Delta \mathrm{G}_{37 / \mathrm{lesion}}^{\circ}, \mathrm{kcal} / \mathrm{mol}$ \\
\hline $\mathrm{dG}\left(N^{2}\right)-3$ ABA duplex & $-95 \pm 8$ & $-252 \pm 24$ & $-21 \pm 1.1$ & $-17.9 \pm 0.8$ & -1.5 \\
Control duplex & $-98 \pm 4$ & $-267 \pm 11$ & $-18.2 \pm 0.5$ & $-14.9 \pm 0.3$ & \\
\hline
\end{tabular}

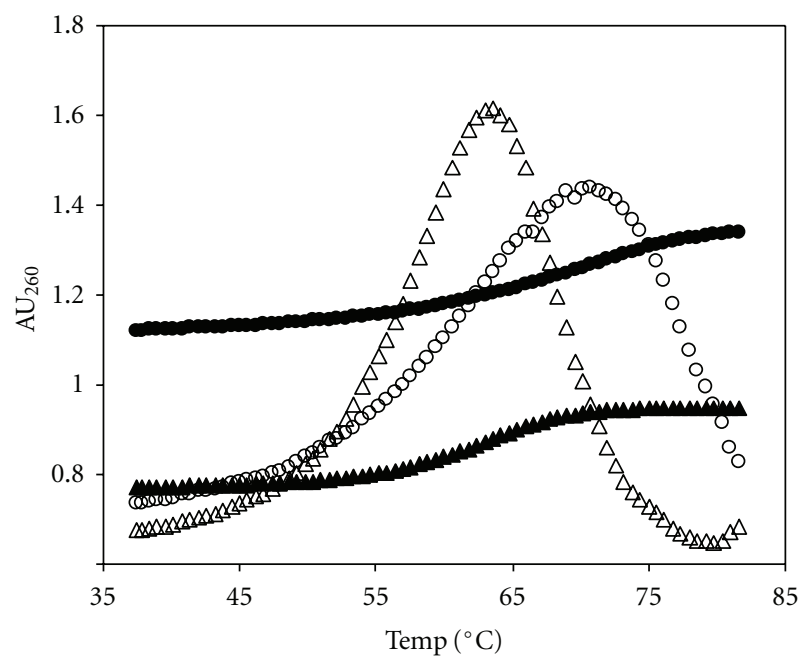

(a)

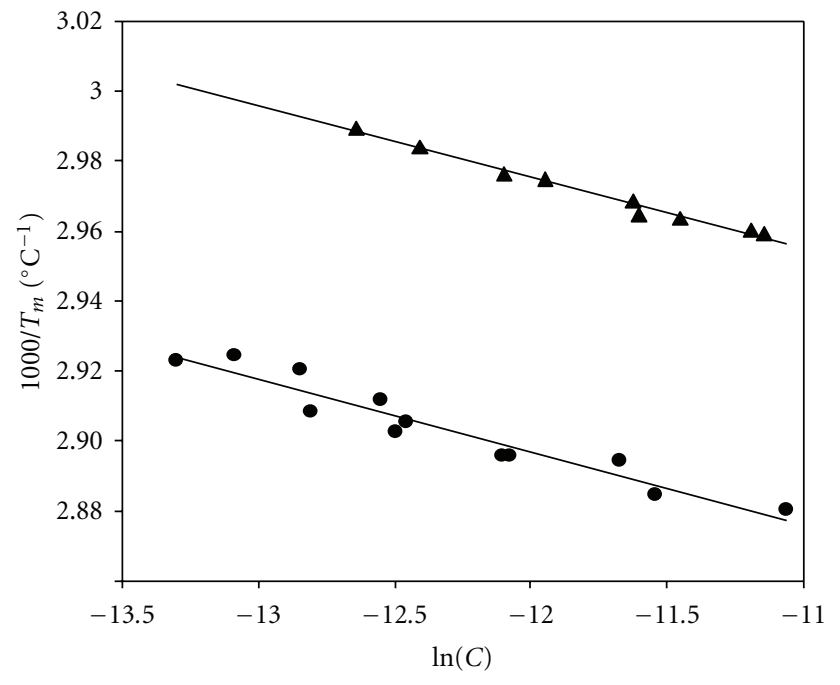

(b)

Figure 4: Typical melting curves of the dG $\left(N^{2}\right)$-3ABA-containing (circles) and unmodified (triangles) 14-mer duplexes, with open symbols showing their first derivative curves $(\mathrm{a}) .\left(1 / T_{m}\right)$ versus $\ln [C]$ plots for the same oligonucleotides $(\mathrm{b})$.

showed that the main product was the desired $\mathrm{dG}\left(N^{2}\right)$ 3ABA containing oligodeoxyribonucleotide (Supplementary Material).

3.2. NMR Spectra of the $d G\left(N^{2}\right)-3 A B A$ Duplex. Two-dimensional NMR spectroscopy confirmed the presence of $3 \mathrm{ABA}$ in the purified sample and allowed the assignment of its aromatic protons (Figure 2). The aromatic region of an NOESY (300 ms mixing time) spectrum in $100 \% \mathrm{D}_{2} \mathrm{O}$ phosphate buffer, $\mathrm{pH} 6.9$, revealed a single set of reasonably sharp proton signals, indicating that the damaged duplex assumes a major stable conformation at room temperature (Figure 2(a)). NOE interactions were particularly strong among $3 \mathrm{ABA}$ protons, readily differentiating them from cross-peaks originated from the aromatic nucleotide protons of the duplex (Figure 2(b)). The identical region of a DQFCOSY spectrum was very simple since its diagonal only shows signals for protons that have scalar coupling, specifically cytosine- $\mathrm{H} 6$ and $3 \mathrm{ABA}$ protons. Thus, the $3 \mathrm{ABA}(\mathrm{H} 1)$ proton was absent on the DQF-COSY spectrum (denoted by an arrow) but exhibited a strong NOE interaction with $3 \mathrm{ABA}(\mathrm{H} 11)$, which is very close in space across the bay region of $3 \mathrm{ABA}$ (Figure 2). From here, identification of the remaining $3 \mathrm{ABA}$ protons was straightforward, with the exceptions of $\mathrm{H} 4$ and $\mathrm{H} 6$ whose specific assignments remained ambiguous. Labels in Figure 2 list the assignment of 3ABA protons.

Figure 3 displays the expanded base- $\mathrm{H}^{\prime}$ sugar proton region of the same $300 \mathrm{~ms}$ mixing time NOESY spectrum.
Each base proton (purine(H8) or pyrimidine(H6)) of the duplex exhibited NOE interactions to its own and the $5^{\prime}$-flanking $\mathrm{H1}^{\prime}$ sugar protons, indicating that the 3ABAdamaged duplex adopts a right-handed helical conformation in solution. The bulky aromatic moiety, however, did induce some perturbations of the ideal B-form conformation, as evidenced by the absence of the A11(H8)-A11(H1') intraresidue interaction (Figure 3, empty box) and the weak intensity detected for the $\mathrm{A} 11(\mathrm{H} 8)-\mathrm{C} 10\left(\mathrm{H}^{\prime}\right)$ and $\mathrm{A} 13(\mathrm{H} 8)-$ $\mathrm{T} 12\left(\mathrm{H}^{\prime}\right)$ cross-peaks. In addition, several proton signals exhibited unusual chemical shift values, including $\mathrm{C} 6\left(\mathrm{H}^{\prime}\right)$ and $\mathrm{A} 11\left(\mathrm{H1}^{\prime}\right)$, that resonate at 4.43 and $5.34 \mathrm{ppm}$, respectively, suggesting that the $3 \mathrm{ABA}$ moiety resides in the duplex minor groove pointing towards the $5^{\prime}$-end of the modified strand. These chemical shift values are reminiscent of those observed on duplexes containing other bulky adducts positioned in minor groove, such as $\mathrm{dG}\left(\mathrm{N}^{2}\right)$-AAF, a minor acetylaminofluorene lesion previously characterized by our laboratory [24], or the extensively studied trans $\mathrm{dG}\left(N^{2}\right)$ $\mathrm{B}[\mathrm{a}] \mathrm{P}$ adducts $[31,32]$.

3.3. Stability of the $d G\left(N^{2}\right)-3 A B A$ Duplex. Analysis of UV melting curves shows that the melting temperature of the self-complementary $\mathrm{dG}\left(N^{2}\right)-3 \mathrm{ABA}$ duplex is about $7.5^{\circ} \mathrm{C}$ higher than that of the unmodified control sample (Figure 4). Van't Hoff thermodynamic parameters for the damaged duplex indicate a large entropy increase that overcompensates for the $2.6 \mathrm{kcal} / \mathrm{mol}$ enthalpy increase, resulting in $3.0 \mathrm{kcal} / \mathrm{mol}$ reduction of Gibbs's free energy at $30^{\circ} \mathrm{C}$ 
<smiles>Nc1c(Nc2nc3c(ncn3C3CC(O)C(CO)O3)c(=O)[nH]2)cc2c3c(cccc13)C(=O)c1ccccc1-2</smiles>

(a)<smiles>CC(=O)Nc1cc2c(cc1Nc1nc3c(ncn3C3CC(O)C(CO)O3)c(=O)[nH]1)-c1ccccc1C2</smiles>

(b)

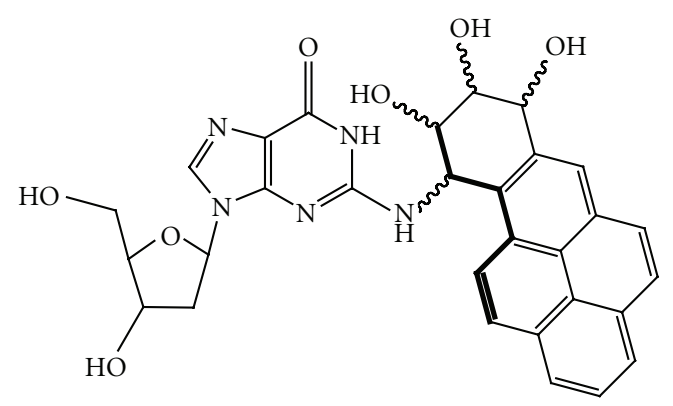

(c)

Figure 5: Bay regions (in bold) of dG- $N^{2}$ adducts formed by 3nitrobenzanthrone (a), acetylaminofluorene (b), and $\mathrm{B}[\mathrm{a}] \mathrm{P}(\mathrm{c})$.

(Table 1). Due to duplex symmetry, there are two dG( $\left.N^{2}\right)$ $3 \mathrm{ABA}$ adducts per duplex molecule, which in principle, can contribute independently to Gibbs's free energy reduction or display additional interactions between themselves. Since the 3ABA duplex has four undamaged G.C base pairs (that showed regular NOE interactions) separating the damaged nucleotides, the ABA moieties are too far apart ( $17 \AA$ in Bform DNA) to expect any direct interaction between them. Therefore, the duplex stabilizing effect of a single $\mathrm{dG}\left(N^{2}\right)$ $3 \mathrm{ABA}$ lesion in the $5^{\prime}$-TXC sequence context is $1.5 \mathrm{kcal} / \mathrm{mol}$ at $30^{\circ} \mathrm{C}$.
Notwithstanding the absence of a refined three-dimensional model of the $\mathrm{dG}\left(N^{2}\right)$-3ABA duplex, it is interesting to compare the stability impact of the different $\mathrm{dG}\left(N^{2}\right)$ minor groove lesions. Our previous study of the $\mathrm{dG}\left(N^{2}\right)$ AAF-containing duplex revealed a considerable stabilization on the double helix by the acetylaminofluorene moiety. The hydrophobic fluorene moiety resides deep in the minor groove of the duplex, displacing water molecules and exposing only $10 \%$ of its surface to solvent. As a result, a significant entropy increase more than compensates for the moderate enthalpy destabilization of the duplex, causing a $1.8 \mathrm{kcal} / \mathrm{mol}$ reduction of Gibb's free energy per lesion [24], somewhat larger that the effect observed here for the $\mathrm{dG}\left(N^{2}\right)$-3ABA adduct. Similar to the AAF case, the $\mathrm{dG}\left(N^{2}\right)$ $3 \mathrm{ABA}$ lesion resides in the duplex minor groove and exhibits an almost identical topology along the bay region edge of the adduct (Figure 5). It is natural to expect, however, that the $3 \mathrm{ABA}$ moiety, being bulkier than the AAF residue, would extend beyond the boundaries of the minor groove, exposing a greater fraction of its hydrophobic ring system to water, thus diminishing the overall stabilizing effect relative to the former. In addition, the $5^{\prime}$ lesion-flanking base pair differs on the $\mathrm{dG}\left(N^{2}\right)$-AAF and $\mathrm{dG}\left(N^{2}\right)$-3ABA duplexes and its contribution to the stability increase can be slightly different. In contrast to the case of the AAF and 3ABA lesions, the presence of $\mathrm{dG}\left(N^{2}\right)-($ trans $) \mathrm{B}[\mathrm{a}] \mathrm{P}$ reduces the thermodynamic stability of the damaged duplex [33]. A main structural difference in the latter case is the topology of the lesion (Figure 5), most importantly the $\mathrm{sp}^{3}$ hybridization of the linkage carbon that results in the exposure of one face of the $\mathrm{B}[\mathrm{a}] \mathrm{P}$ moiety to solvent $[31,32]$. In addition, differences on sequence context between the $\mathrm{dG}\left(N^{2}\right)-3 \mathrm{ABA}$ and $\mathrm{dG}\left(N^{2}\right)$-(trans)B[a]P lesion may also play a role in explaining the stability effects of these adducts.

The DNA stabilizing effect of $\mathrm{dG}\left(N^{2}\right)-3 \mathrm{ABA}$ is shared by only few bulky lesions, specifically the $\mathrm{dG}\left(N^{2}\right)$ - $\mathrm{AAF}$ adduct [24], the dG(N7) and fapy-dG adducts of aflatoxin $\mathrm{B}_{1}[34,35]$. In contrast to $\mathrm{AAF}$ and aflatoxin $\mathrm{B}_{1}, 3-$ nitrobenzanthrone is an abundant environmental pollutant in developed countries and the properties of 3-NBA generated lesions may help explain the incidence of random mutations and sporadic cancers. The current models of the nucleotide excision repair (NER) pathway postulates that the recognition of bulky lesions is mediated by sensing the local instability [36-38] or alteration of conformational mobility [39] induced by the adducts. In excellent agreement with these concepts, the increased thermodynamic stability of duplex DNA containing $\mathrm{dG}\left(\mathrm{N}^{2}\right)$-AAF adducts correlates well with the unusually long lifetime of this lesion in rat genomic DNA [25]. Recent studies have found that $\mathrm{dG}\left(N^{2}\right)-3 \mathrm{ABA}$ persists in rat DNA for a long period of time after a single instillation of 3NBA [21]. Our observations that $\mathrm{dG}\left(N^{2}\right)-3 \mathrm{ABA}$ increases duplex stability and adopts a single conformation in solution point to a mechanistic explanation for its persistence in cellular DNA. However, a careful examination of the recognition of the $\mathrm{dG}\left(\mathrm{N}^{2}\right)$ 3ABA damage by the NER system is needed before these ideas can be confirmed. Such investigations and the NMR 
structure determination of $\mathrm{dG}\left(\mathrm{N}^{2}\right)-3 \mathrm{ABA}$-containing DNA are currently in progress.

\section{Conclusions}

The environmental pollutant 3-nitrobenzanthrone is one of the most potent bacterial mutagens and has strong mutagenic activity in mammalian cells. After cellular activation to electrophilic intermediates, it reacts with DNA forming purine adducts including the prevalent $\mathrm{dG}\left(N^{2}\right)-3 \mathrm{ABA}$ lesion. We reported here an efficient synthetic method for incorporation of this lesion in oligomeric DNA in any sequence context, opening the door to future site-specific mutagenesis and DNA repair studies. We also presented evidence showing that $\mathrm{dG}\left(N^{2}\right)-3 \mathrm{ABA}$ increases the stability of the damaged duplex, a finding previously observed with other $\mathrm{dG}\left(N^{2}\right)$ lesions and that is associated with the long persistence of the adducts in rat tissues. Our results suggest that the lack of thermodynamic destabilization of DNA is a key factor during the recognition of bulky the lesions by the NER pathway.

\section{Acknowledgments}

Grant no. ES017368 from the National Institutes of Health supported this research. The authors thank Robert Rieger and the Proteomic Facility of Stony Brook University for high-resolution mass spectra. Shared instrumentation grant S10-RR023680-1 supports the Proteomic Facility at Stony Brook University. They also thank Dr. Shibani Bhattacharya, Dr. Kaushik Dutta, and Dr. Michael Goger (New York Structural Biology Center) for their assistance. The Center is a STAR center supported by the New York State Office of Science, Technology, and Academic Research. NMR resources are supported by NIH P41 GM66354.

\section{References}

[1] H. S. Rosenkranz, "Mutagenic nitroarenes, diesel emissions, particulate-induced mutations and cancer: an essay on cancercausation by a moving target," Mutation Research, vol. 367, no. 2, pp. 65-72, 1996.

[2] T. Enya, H. Suzuki, T. Watanabe, T. Hirayama, and Y. Hisamatsu, "3-Nitrobenzanthrone, a powerful bacterial mutagen and suspected human carcinogen found in diesel exhaust and airborne particulates," Environmental Science and Technology, vol. 31, no. 10, pp. 2772-2776, 1997.

[3] P. T. Phousongphouang, A. J. Grosovsky, D. A. Eastmond, M. Covarrubias, and J. Arey, "The genotoxicity of 3-nitrobenzanthrone and the nitropyrene lactones in human lymphoblasts," Mutation Research, vol. 472, no. 1-2, pp. 93-103, 2000.

[4] H. Nishida, M. Kawanishi, T. Takamura-Enya, and T. Yagi, "Mutagenic specificity of $\mathrm{N}$-acetoxy-3-aminobenzanthrone, a major metabolically activated form of 3-nitrobenzanthrone, in shuttle vector plasmids propagated in human cells," Mutation Research, vol. 654, no. 1, pp. 82-87, 2008.

[5] V. M. Arlt, L. Zhan, H. H. Schmeiser et al., "DNA adducts and mutagenic specificity of the ubiquitous environmental pollutant 3-nitrobenzanthrone in Muta Mouse," Environmental and Molecular Mutagenesis, vol. 43, no. 3, pp. 186-195, 2004.
[6] V. M. Arlt, J. Gingerich, H. H. Schmeiser, D. H. Phillips, G. R. Douglas, and P. A. White, "Genotoxicity of 3-nitrobenzanthrone and 3-aminobenzanthrone in Muta Mouse and lung epithelial cells derived from MutaMouse," Mutagenesis, vol. 23, no. 6, pp. 483-490, 2008.

[7] J. Vom Brocke, A. Krais, C. Whibley, M. C. Hollstein, and H. H. Schmeiser, "The carcinogenic air pollutant 3-nitrobenzanthrone induces GC to TA transversion mutations in human p53 sequences," Mutagenesis, vol. 24, no. 1, pp. 17-23, 2009.

[8] E. Lamy, F. Kassie, R. Gminski, H. H. Schmeiser, and V. Mersch-Sundermann, "3-Nitrobenzanthrone (3-NBA) induced micronucleus formation and DNA damage in human hepatoma (HepG2) cells," Toxicology Letters, vol. 146, no. 2, pp. 103-109, 2004.

[9] V. M. Arlt, K. J. Cole, and D. H. Phillips, "Activation of 3-nitrobenzanthrone and its metabolites to DNA-damaging species in human B lymphoblastoid MCL-5 cells," Mutagenesis, vol. 19, no. 2, pp. 149-156, 2004.

[10] E. Nagy, M. Zeisig, K. Kawamura et al., "DNA adduct and tumor formations in rats after intratracheal administration of the urban air pollutant 3-nitrobenzanthrone," Carcinogenesis, vol. 26, no. 10, pp. 1821-1828, 2005.

[11] P. Vineis, F. Forastiere, G. Hoek, and M. Lipsett, "Outdoor air pollution and lung cancer: recent epidemiologic evidence," International Journal of Cancer, vol. 111, no. 5, pp. 647-652, 2004.

[12] E. Garshick, F. Laden, J. E. Hart et al., "Lung cancer in railroad workers exposed to diesel exhaust," Environmental Health Perspectives, vol. 112, no. 15, pp. 1539-1543, 2004.

[13] V. M. Arlt, M. Stiborova, C. J. Henderson et al., "Environmental pollutant and potent mutagen 3-nitrobenzanthrone forms DNA adducts after reduction by $\mathrm{NAD}(\mathrm{P}) \mathrm{H}$ :quinone oxidoreductase and conjugation by acetyltranferases and sulfotransferases in human hepatic cytosols," Cancer Research, vol. 65, no. 7, pp. 2644-2652, 2005.

[14] M. Stiborová, H. Dračínská, J. Mizerovská et al., “The environmental pollutant and carcinogen 3-nitrobenzanthrone induces cytochrome $\mathrm{P} 4501 \mathrm{Al}$ and $\mathrm{NAD}(\mathrm{P}) \mathrm{H}$ :quinone oxidoreductase in rat lung and kidney, thereby enhancing its own genotoxicity," Toxicology, vol. 247, no. 1, pp. 11-22, 2008.

[15] V. M. Arlt, M. Stiborova, A. Hewer, H. H. Schmeiser, and D. H. Phillips, "Human enzymes involved in the metabolic activation of the environmental contaminant 3-nitrobenzanthrone: evidence for reductive activation by human NADPH:Cytochrome P450 reductase," Cancer Research, vol. 63, no. 11, pp. 2752-2761, 2003.

[16] A. Seidel, D. Dahmann, H. Krekeler, and J. Jacob, "Biomonitoring of polycyclic aromatic compounds in the urine of mining workers occupationally exposed to diesel exhaust," International Journal of Hygiene and Environmental Health, vol. 204, no. 5-6, pp. 333-338, 2002.

[17] V. M. Arlt, A. Hewer, B. L. Sorg, H. H. Schmeiser, D. H. Phillips, and M. Stiborova, "3-Aminobenzanthrone, a human metabolite of the environmental pollutant 3-nitrobenzanthrone, forms DNA adducts after metabolic activation by human and rat liver microsomes: evidence for activation by cytochrome P450 1A1 and P450 1A2," Chemical Research in Toxicology, vol. 17, no. 8, pp. 1092-1101, 2004.

[18] V. M. Arlt, C. J. Henderson, C. R. Wolf, H. H. Schmeiser, D. H. Phillips, and M. Stiborova, "Bioactivation of 3-aminobenzanthrone, a human metabolite of the environmental pollutant 3-nitrobenzanthrone: evidence for DNA adduct 
formation mediated by cytochrome P450 enzymes and peroxidases," Cancer Letters, vol. 234, no. 2, pp. 220-231, 2006.

[19] V. M. Arlt, B. L. Sorg, M. Osborne et al., "DNA adduct formation by the ubiquitous environmental pollutant 3-nitrobenzanthrone and its metabolites in rats," Biochemical and Biophysical Research Communications, vol. 300, no. 1, pp. 107114, 2003.

[20] C. A. Bieler, M. G. Cornelius, R. Klein et al., "DNA adduct formation by the environmental con taminant 3-Nitrobenzanthrone after intratracheal instillation in rats," International Journal of Cancer, vol. 116, no. 6, pp. 833-838, 2005.

[21] C. A. Bieler, M. G. Cornelius, M. Stiborova et al., "Formation and persistence of DNA adducts formed by the carcinogenic air pollutant 3-nitrobenzanthrone in target and non-target organs after intratracheal instillation in rats," Carcinogenesis, vol. 28, no. 5, pp. 1117-1121, 2007.

[22] V. M. Arlt, H. H. Schmeiser, M. R. Osborne et al., "Identification of three major DNA adducts formed by the carcinogenic air pollutant 3-nitrobenzanthrone in rat lung at the $\mathrm{C} 8$ and N2 position of guanine and at the N6 position of adenine," International Journal of Cancer, vol. 118, no. 9, pp. 2139-2146, 2006.

[23] T. Takamura-Enya, M. Kawanishi, T. Yagi, and Y. Hisamatsu, "Structural identification of DNA adducts derived from 3nitrobenzanthrone, a potent carcinogen present in the atmosphere," Chemistry, vol. 2, no. 9, pp. 1174-1185, 2007.

[24] T. Zaliznyak, R. Bonala, F. Johnson, and C. De Los Santos, "Structure and stability of duplex DNA containing the 3-(deoxyguanosin- N2-yl)-2-acetylaminofluorene (dG(N2)AAF) lesion: a bulky adduct that persists in cellular DNA," Chemical Research in Toxicology, vol. 19, no. 6, pp. 745-752, 2006.

[25] X. S. Cui, L. C. Eriksson, and L. Möller, "Formation and persistence of DNA adducts during and after a long-term administration of 2-nitrofluorene," Mutation Research, vol. 442, no. 1, pp. 9-18, 1999.

[26] K. J. Breslauer, "Extracting thermodynamic data from equilibrium melting curves for oligonucleotide order-disorder transitions," Methods in Enzymology, vol. 259, pp. 221-242, 1995.

[27] F. Delaglio, S. Grzesiek, G. W. Vuister, G. Zhu, J. Pfeifer, and A. Bax, "NMRPipe: a multidimensional spectral processing system based on UNIX pipes," Journal of Biomolecular NMR, vol. 6, no. 3, pp. 277-293, 1995.

[28] T. D. Goddard and D. G. Kneller, SPARKY 3, University of California, San Francisco, Calif, USA.

[29] R. R. Bonala, M. C. Torres, S. Attaluri, C. R. Iden, and F. Johnson, "Incorporation of N2-deoxyguanosine metabolic adducts of 2-aminonaphthalene and 2-aminofluorene into oligomeric DNA," Chemical Research in Toxicology, vol. 18, no. 3, pp. 457-465, 2005.

[30] F. De Riccardis and F. Johnson, "Chemical synthesis of crosslinked purine nucleosides," Organic Letters, vol. 2, no. 3, pp. 293-295, 2002.

[31] M. Cosman, C. De los Santos, R. Fiala et al., "Solution conformation of the major adduct between the carcinogen (+)anti- benzo[a]pyrene diol epoxide and DNA," Proceedings of the National Academy of Sciences of the United States of America, vol. 89, no. 5, pp. 1914-1918, 1992.

[32] C. De los Santos, M. Cosman, B. E. Hingerty et al., "Influence of benzo[a]pyrene diol epoxide chirality on solution conformations of DNA covalent adducts: the (-)-trans-anti-[BP]G .
$\mathrm{C}$ adduct structure and comparison with the (+)-trans-anti[BP]G · C enantiomer," Biochemistry, vol. 31, no. 23, pp. 5245-5252, 1992.

[33] L. A. Marky, D. Rentzeperis, N. P. Luneva, M. Cosman, N. E. Geacintov, and D. W. Kupke, "Differential hydration thermodynamics of stereoisomeric DNA-benzo[a]pyrene adducts derived from diol epoxide enantiomers with different tumorigenic potentials," Journal of the American Chemical Society, vol. 118, no. 16, pp. 3804-3810, 1996.

[34] S. Gopalakrishnan, T. M. Harris, and M. P. Stone, "Intercalation of aflatoxin B1 in two oligodeoxynucleotide adducts: comparative $1 \mathrm{H}$ NMR analysis of $\mathrm{d}\left(\mathrm{ATC}^{A F B} \mathrm{GAT}\right) \cdot \mathrm{d}(\mathrm{ATCGAT}) \quad$ and $\mathrm{d}\left(\mathrm{AT}^{A F B} \mathrm{GCAT}\right) 2$, Biochemistry, vol. 29, no. 46, pp. 10438-10448, 1990.

[35] H. Mao, Z. Deng, F. Wang, T. M. Harris, and M. P. Stone, "An intercalated and thermally stable FAPY adduct of aflatoxin B1 in a DNA duplex: structural refinement from 1H NMR," Biochemistry, vol. 37, no. 13, pp. 4374-4387, 1998.

[36] D. Gunz, M. T. Hess, and H. Naegeli, "Recognition of DNA adducts by human nucleotide excision repair. Evidence for a thermodynamic probing mechanism," Journal of Biological Chemistry, vol. 271, no. 41, pp. 25089-25098, 1996.

[37] N. E. Geacintov, S. Broyde, T. Buterin et al., "Thermodynamic and structural factors in the removal of bulky DNA adducts by the nucleotide excision repair machinery," Biopolymers, vol. 65, no. 3, pp. 202-210, 2002.

[38] Y. Cai, S. Ding, N. E. Geacintov, and S. Broyde, "Intercalative conformations of the $14 \mathrm{R}(+)$ - and $14 \mathrm{~S}(-)$ - trans-antiDB[a,1]P- N6-dA adducts: molecular modeling and MD simulations," Chemical Research in Toxicology, vol. 24, no. 4, pp. 522-531, 2011.

[39] R. J. Isaacs and H. P. Spielmann, "A model for initial DNA lesion recognition by NER and MMR based on local conformational flexibility," DNA Repair, vol. 3, no. 5, pp. 455-464, 2004. 

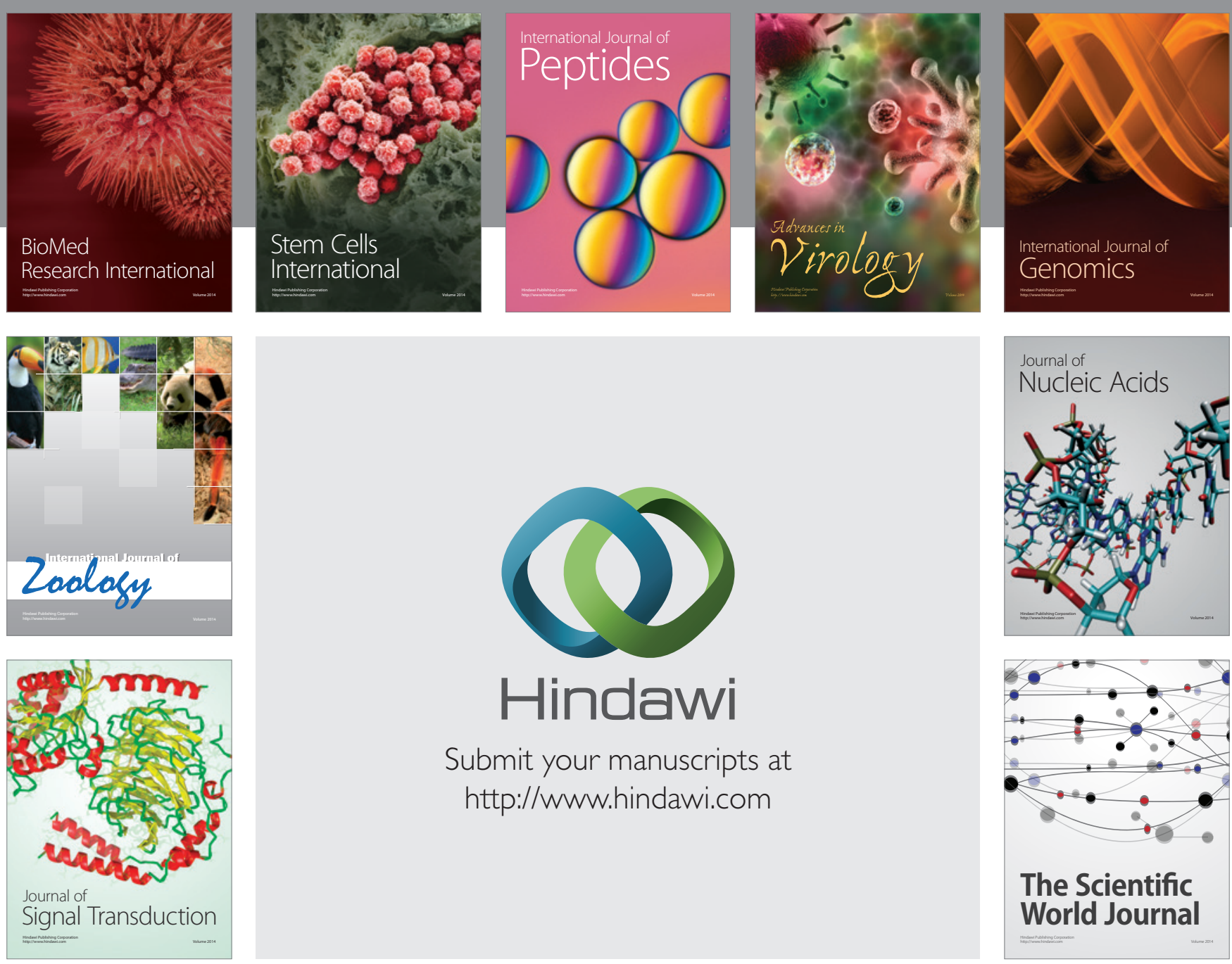

Submit your manuscripts at

http://www.hindawi.com
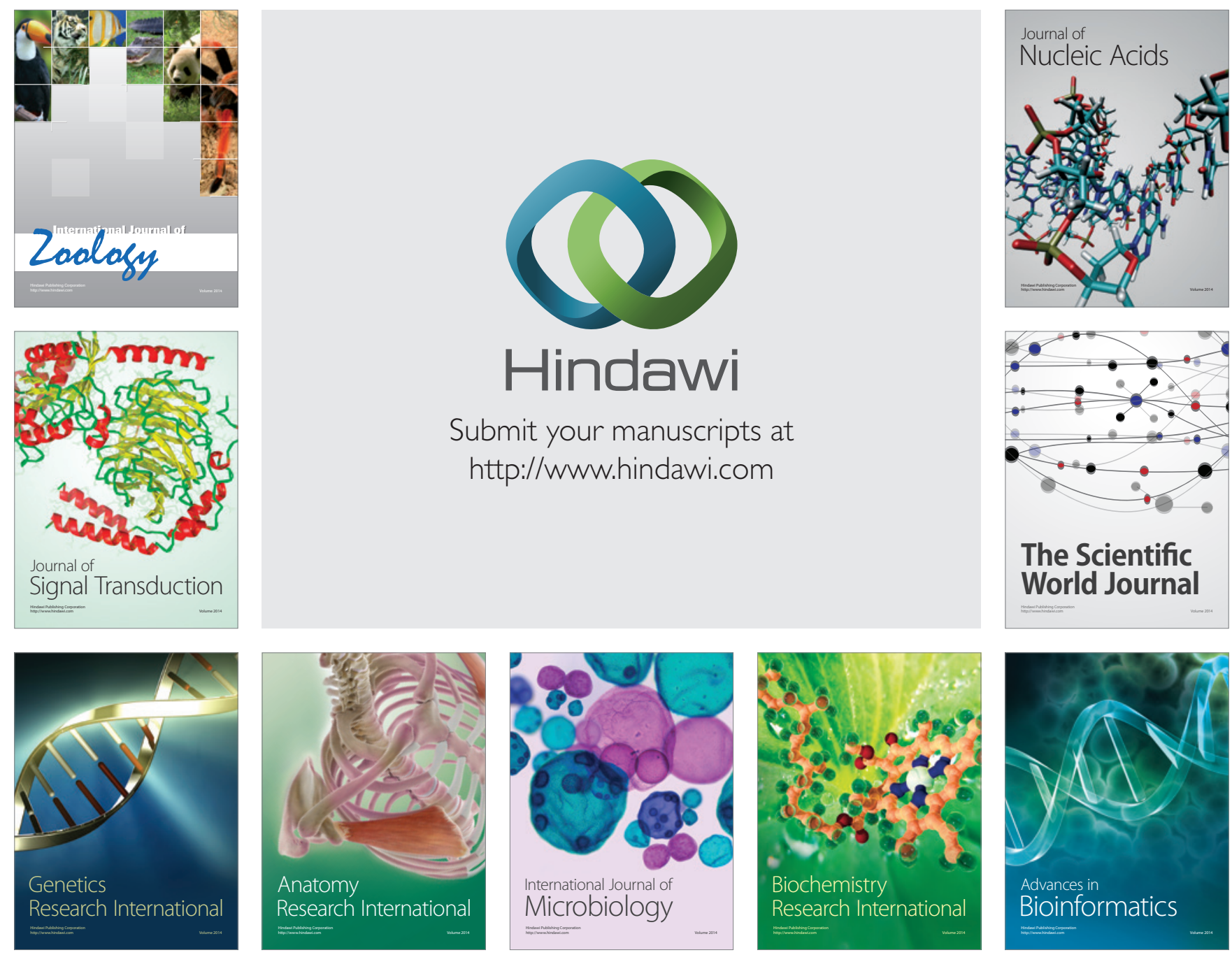

The Scientific World Journal
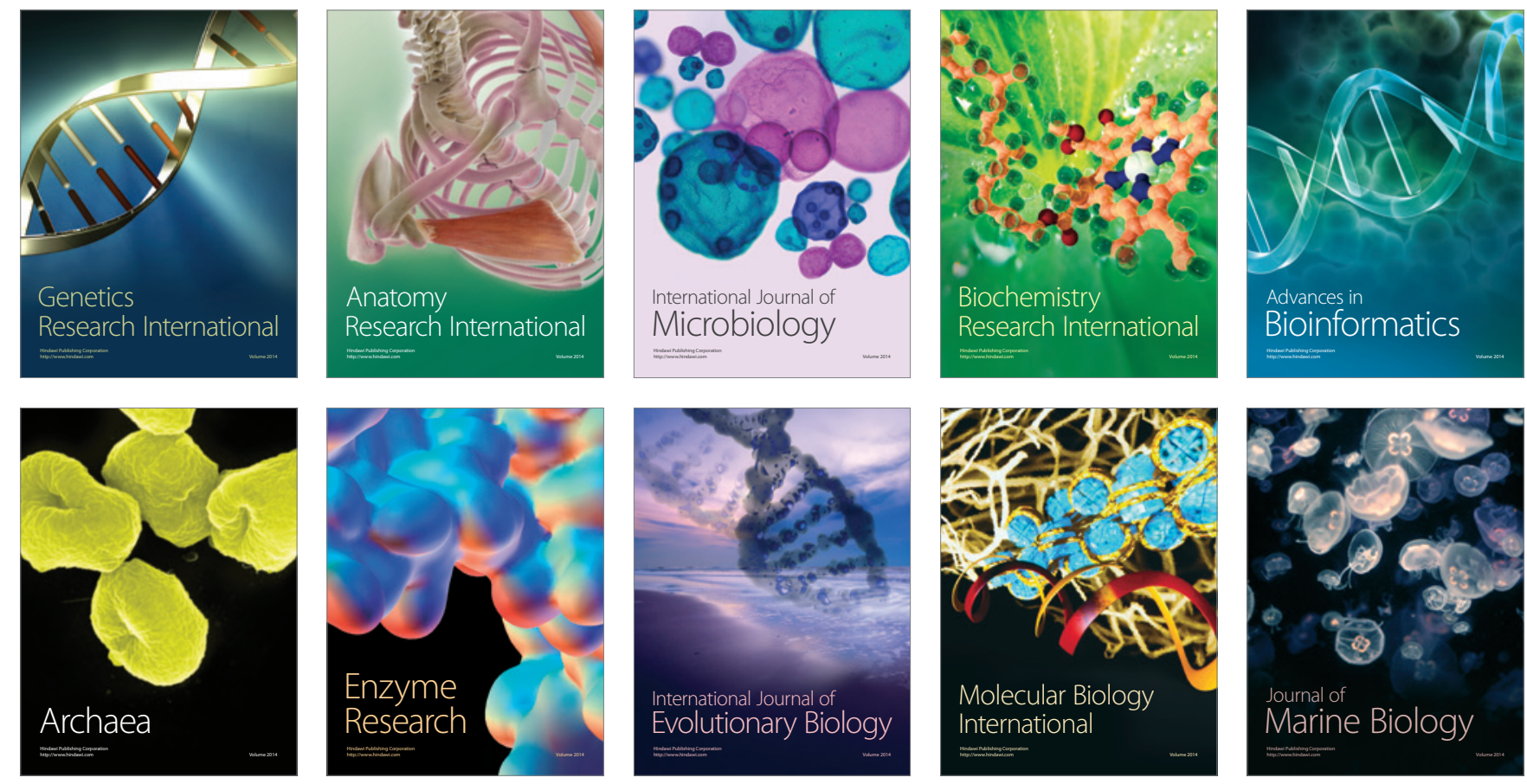